\title{
The Weeds of Arable Land in relation to the Soils on which they grow. II.
}

\author{
BY \\ WINIFRED E. BRENCHLEY, D.SC., F.L.S. \\ Lawes Agricultural Trust, Rothamsted.
}

DRING the season of I9I0 an investigation was carried on in certain 1 parts of Bedfordshire to determine the relation between the weeds of arable land, the crop grown, and the soils upon which they grow.

It was recognized at the outset that the results must be regarded as tentative in nature until confirmatory evidence was obtained from similar work carried out in other parts of the country, on soils both of the same and different geological derivation. Consequently in I9II the field of investigation was transferred to certain parts of Wiltshire and Somerset, to districts round Warminster (Upper Greensand), Shrewton (Chalk), and Bath (Clay). In that part of the country a large number of geological formations crop out within a comparatively short distance, but attention was confined to two or three main types of soil.

In the area investigated no sand was available to compare with the Lower Greensand of Bedfordshire, the soils of the Upper Greensand being generally rather heavy. In place of the Oxford and Gault clays (here only represented by pasture), which are non-calcareous in nature, the calcareous clays of the Oolite and Lias series came under consideration.

The working plan adopted was the same as in I9I0; the areas were characterized by the comparative absence of hedges, which greatly facilitated the work.

The relative prevalence of the weeds was again noted as :-

(I) Dominant.

(2) Sub-dominant.

(3) Distributed.

(4) Occasional.

(5) Scarce or rare.

During the season's survey 106 species of weeds were met with, representing 74 genera. Of these 29 species, representative of 26 genera, were [Annals of Botany, Vol. XXVI. No. CI. January, 1912.] 
each seen once or twice only. As in the previous investigation, attention was confined to those weeds growing in among the crop, the weeds of the surrounding hedgerows being left out of consideration. The classification of the soils did not present so much difficulty as in the case of the Bedfordshire work. The areas dealt with were much larger, and adjoining fields did not show the sudden change in the nature of the soil that occurred so frequently in the eastern county. In the chalk areas rather more subdivision had to be made this year. The presence or absence of lime in the various soils was frequently tested for with dilute hydrochloric acid.

The seasons in the two years of investigation were of totally different character, that of I9I0 being wet and cold, with a deficiency of sunshine, while that of I9II was characterized by an excessive amount of sunshine and by high temperatures, coupled with a low rainfall, so that conditions of drought prevailed. This radical difference may have influenced the relative occurrence of certain species, so that it is quite probable that some of the diversity in results may be due to seasonal variation rather than to the actual differences in the nature of the soil.

The chief species of weeds, with their habitats and dominance, were as follows :-

Ranunculaceae. Ranunculus acris. Found on clay and sand. Absent from chalk. Never dominant.

Ranunculus arvensis. Chiefly found on clay, once on chalk. Never dominant. (Rarely seen in this district; far less frequent than in Bedfordshire.)

Ramunculus repens. Most frequent on chalky soils; also seen on clay containing a fair proportion of lime. (N.B.-It is possible that in the Bedfordshire districts $R$. repens occurred in some instances, but was not separated from $R$. acris.) Never dominant.

Papaveraceae. Papaver hybridum. Only occasionally seen, then on chalky soil. Never dominant.

Papaver Rhoeas. Characteristic of chalky soils; hardly seen elsewhere. Occasionally dominant. (Many observations of poppies were made when the plants were too small to permit the species to be identified. These usually occurred on chalky soils, with one record (dominant) from sand.)

Fumariaceae. Fumaria officinalis. Chiefly on chalky soils, but fairly frequent on loam. Several records from clay, but then it was usually occasional or scarce in distribution. Occasionally dominant on chalk or loam.

Cruciferae. Brassica alba. Practically confined to chalk and brashy loam (limestone). Frequently dominant; one instance of dominance on clay, which proved to contain much limestone.

Brassica Sinapis. Chiefly on chalk and red land; also much on clay 
and loam. No record from ordinary sand. Frequently dominant on all types of soil, including 'bake'. (This plant is perhaps more widely distributed in area than in Bedfordshire, but as it is not so abundant in quantity in the West Country, it is consequently less in evidence.)

Capsella Bursa-pastoris. Practically confined to clay and loam. Never dominant.

Resedaceae. Reseda lutea. Characteristic of chalk, but only occurring in very small quantity.

Violaceae. Viola tricolor. Practically confined to chalky soils. Very rare on clay. Never dominant.

Caryophyllaceae. Arenaria serpyllifolia. Occasionally found, usually 'on chalky soils. Never dominant.

Cerastium vulgatum. Distributed on various types of soil, but seldom seen and never very prevalent.

Lychnis Githago. Confined to chalk. Once dominant.

Lychnis vespertina. Chiefly on chalky soils, sometimes on clay and loam. Of frequent occurrence as an occasional or scarce weed.

Silene Cucubalus. Chiefly on chalky soils ; occasionally on clay, where it was once dominant.

Stellaria media. Universally distributed. Occasionally dominant on any soil.

Rosaceae. Potentilla anserina. Occasionally seen on chalky soils and clay. Once dominant on chalk.

Umbelliferae. Daucus Carota. Generally found on pure chalk, sometimes on chalky loam. Never dominant, usually only occasional.

Heracleum Sphondylium. Characteristic of chalky soils. Never dominant.

Scandix Pecten. Characteristic of chalky soils. Very occasional elsewhere. Once dominant on red land.

Rubiaceae. Galium Aparine. Generally distributed. Rarely dominant or sub-dominant, though of very frequent occurrence.

Sherardia arvensis. Rarely seen, but then chiefly on chalk in very small quantities. seen.

Valerianeae. Valerianella olitoria. Confined to chalk. Rarely

Dipsaceae. Scabiosa arvensis. Characteristic of chalk soils. Never dominant.

Compositae. Anthemis sp. Chiefly on clay or loam, but distributed over other soils. Once dominant on clay.

Carduus arvensis. Universally distributed and very common. Dominant on any soil.

Centaurea nigra. Chiefly found on chalk and red land; only occasionally recorded from other soils. Never dominant. 
Senecio vulgaris. Universally distributed, but by no means so frequent in occurrence as in Bedfordshire. Never dominant.

Sonchus arvensis. Generally distributed, but chiefly on chalk and clay. Frequently dominant on chalk, also dominant on clay and sand.

Taraxacum dens-leonis. Recorded most frequently from chalky soils, but also occurs on all other types. Never dominant.

Tussilago Farfara. Chiefly on clay, but frequent on other soils. Dominant on clay and chalk.

Primulaceae. Anagallis arvensis. Distributed over various types of soil but rarely in any quantity. It does not seem to appreciate chalky soils. Never dominant ; once sub-dominant on 'bake'.

Convolvulaceae. Convolvulus arvensis. Universally distributed as to soil and dominant anywhere. One of the most commonly occurring weeds.

Boraginaceae. Lithospermum arvense. Characteristic of chalky soils. Never dominant.

Myosotis arvensis. Confined to chalky soils. Never dominant.

Orobanchaceae. Orobanche minor. Only recorded from one district on chalky soils. Never dominant.

Scrophulariaceae. Bartsia Odontites. Practically confined to chalky soils; very occasional on clay. Never dominant.

Linaria spuria. Occasionally recorded from the lighter soils-loam and red land. Never dominant.

Linaria vulgaris. Characteristic of chalky soils. Never dominant.

Veronica agrestis. Found on all types of soil. Never dominant.

Veronica hederaefolia. Recorded from all types of soil, but only dominant in one place, on chalk.

Labiatae. Mentha arvensis. Chiefly found on clay soils; probably characteristic of heavy land. Never dominant, once sub-dominant on clay.

Plantagineae. Plantago lanceolata. Practically confined to chalky soils. Never dominant.

Plantago major. Recorded from all types of land, but chiefly found on clay and chalky soils. Never dominant.

Plantago media. Confined to clay; never seen on chalk. Never dominant.

Illecebraceae. Sceleranthus anmuns. Only seen on 'bake'.

Chenopodiaceae. Chenopodium album. Universally distributed both as to soil and dominance.

Polygonaceae. Polygonum aviculare. Chiefly found on chalk and clay. Often dominant on both types.

Polygonum Convolvulus. Chiefly on clay and chalky soils. Never dominant. 

soils.)

Rumex Acetosella. Only seen on 'bake'. (Characteristic of acid sandy

Rumex crispus. Most frequent on chalky soils, but often seen on clay and other types of land. Occasionally dominant on sand and red land.

Euphorbiaceae. Euphorbia exigua. Chiefly on clay, but frequent on other soils. Never dominant, but occasionally sub-dominant on clay.

Euphorbia Helioscopia. Fairly well distributed, but most frequent on chalky soils and loam. Never dominant, usually only occasional or scarce.

Liliaceae. Ornithogalum pyrenaicum. Characteristic of heavy clay soils in the Bath district. Rare.

Gramineae. Alopecurus agrestis. Occurred on various types of soil. Occasionally dominant on chalk.

Arrhenatherum avenaceum var. tuberosum. Distributed as to soil. Once dominant on 'black gravel'.

Bromus arvensis and $B$. sterilis. Very seldom seen, then only on chalk.

Lolium perenne. Only on chalk and clay. Never dominant.

Poa anmua. Chiefly on clay, but also found on other soils. Never dominant.

Poa pratensis. Only recorded from chalk. Once dominant.

Poa trivialis. Universal in distribution. Once dominant on clay.

Triticum repens. Universal in distribution. Dominant on heavy land.

Equisetaceae. Equisetum arvense. Universally distributed as to soil, but not very frequent in occurrence. Once dominant on clay.

Analyses of the data have been made showing the distribution of the various weeds on the different soils. It must be remembered that a weed that is 'absent' from any particular soil may occur in isolated instances in that very habitat, in which case it is usually only occasional or very rare in distribution.

\section{A. Clay and Heavy Brashy Soils.}

In the districts round Inglescombe and Inglesbatch, near Bath, the land is of an exceptionally heavy nature, being a very sticky clay, which needs special care and methods to farm it properly. During the hot weather it bakes very badly and opens out into deep cracks. This soil is derived from three geological formations which crop out in succession up the hillsides, and it is characteristically calcareous on account of the limestone which occurs with it, in contradistinction to the non-calcareous clays worked in Bedfordshire.

I. Inferior Oolite; soil very reddish in colour and generally brashy in nature. Contains much limestone. 
2. Fuller's earth; an argillaceous deposit between I and 3. Below the surface this appears as a very sticky yellow clay.

3. Bath or Great Oolite; clay and limestone.

In the Wilmington district, on the further side of the valley from the above, the soil is derived from-

I. Lower Lias ; clay and limestone.

2. Inferior Oolite.

[In both these districts there is an outcrop of the Midford Sands, but this is generally either wooded or under pasture, and so does not affect the investigation in hand.]

The derivation of the soils does not appear to affect the varieties of plants occurring, as the different species of clay weeds were found indiscriminately on land derived from all the four geological formations, all being calcareous in nature.

The number of species occurring was relatively less than those found on chalky soils, and the majority of the plants were such as occurred on any type of soil, hardly one appearing to be symptomatic of clay. A very few species, however, were chiefly associated with clay, though occurring on other types of soil as well, and one, Plantago media, appears to be confined to clay in this district.

Plantago media-practically confined to clay.

Capsella Bursa-pastoris-also recorded from loam.

Mentha arvensis

Poa annua

Ranunculus arvensis

chiefly found on clay, but also

Tussilago Farfara seen on other soils.

Ranunculus acris-also on sand.

Brassica alba

Euphorbia exigua

Plantago major

Polygonum aviculare

also on chalk.

„ Convolvulus

Potentilla anserina

\section{B. Chalk.}

The chalk districts investigated were chiefly on the Wiltshire Downs in the neighbourhood of Shrewton and Stonehenge, a radius of some four miles being worked. Data were also obtained from the chalk at Heytesbury and Sutton Veny, not far from Warminster. The whole of the soils were derived from the chalk formation, though for convenience of working and classification they were subdivided into- 
relation to the Soils on which they grow. II.

(a) Chalk, where the soil was white or very light in colour.

(b) Red Land, lying above (a), rather darker in colour and perhaps a little heavier in texture.

(c) Chalky loam, very light calcareous soil, but slightly heavier than the above.

The noticeable feature of the weed flora is the large number of species occurring, many of which are essentially characteristic or even symptomatic of chalk. In both these respects the flora is in marked contrast to that of the clay soils.

\begin{tabular}{|c|c|}
\hline $\begin{array}{l}\text { Bromus arvensis } \\
\qquad " \text { sterilis } \\
\text { Campanula hybrida } \\
\text { Daucus Carota } \\
\text { Linaria spuria } \\
\text { " vulgaris } \\
\text { Lychnis Githago } \\
\text { Myosotis arvensis } \\
\text { Poa pratensis } \\
\text { Reseda lutea }\end{array}$ & ned to chalky soil. \\
\hline $\begin{array}{l}\text { Centaurea nigra } \\
\text { Heracleum Sphondylium } \\
\text { Lithospermum arvense } \\
\text { Papaver Rhoeas } \\
\text { Plantago lanceolata } \\
\text { Scabiosa arvensis } \\
\text { Scandix Pecten } \\
\text { Sherardia arvensis } \\
\text { Viola tricolor }\end{array}$ & $\begin{array}{l}\text { very characteristic of chalk, } \\
\text { but occasionally seen on } \\
\text { other soils. }\end{array}$ \\
\hline $\begin{array}{l}\text { Arenaria serpyllifolia } \\
\text { Bartsia Odontites } \\
\text { Brassica Sinapis } \\
\text { Fumaria officinalis } \\
\text { Lychnis vespertina } \\
\text { Papaver sp. } \\
\text { Ranunculus repens } \\
\text { Silene Cucubalus }\end{array}$ & $\begin{array}{l}\text { chiefly on chalk, sometimes } \\
\text { on clay. }\end{array}$ \\
\hline $\begin{array}{l}\text { Brassica alba } \\
\text { Euphorbia exigua } \\
\text { Plantago major } \\
\text { Polygonum aviculare } \\
\qquad, \text { Convolvulus } \\
\text { Potentilla anserina }\end{array}$ & equally abundant on clay. \\
\hline
\end{tabular}




\section{C. 'Bake.'}

This is a thin layer of soil, often only a few inches thick, overlying the chalk on the top of some of the Downs. Instead of being calcareous, this layer is destitute of lime, and is indeed sandy and acid in nature, of a red colour. The local theory is that for some reason or other the lime has been entirely washed out from the soil and carried down, leaving a non-calcareous residue. The peculiar nature of the soil is reflected in the flora, the abrupt change from the typical chalk flora being quite startling in its suddenness. Unfortunately very little of the land was accessible. The number of species was relatively few, and the quantity of weed was comparatively scanty.

The actual weed flora may prove of interest:

$\left.\begin{array}{l}\text { Brassica Sinapis } \\ \text { Geranium sp. } \\ \text { Scleranthus annuus }\end{array}\right\}$ dominant in
Anagallis arvensis - sub-dominant
$\left.\begin{array}{l}\text { Carduus arvensis } \\ \text { Rumex Acetosella }\end{array}\right\}$ occasional.
$\left.\begin{array}{l}\text { Poa trivialis } \\ \text { Scandix Pecten } \\ \text { Spergula arvensis }\end{array}\right\}$ scarce.

The presence of Rumex Acetosella and Spergula arvensis is most significant, as these are unfailing indicators of an acid soil. The prevalence of Anagallis arvensis is also noteworthy, as on the chalky soil very few plants of this species are to be seen.

While so many species are more or less definitely associated with particular soils, others are universally distributed, and occur on various types of soil, on any of which they may be dominant. A few plants, while universal, are more particularly associated with chalk.

\section{Weeds of universal occurrence.}

Alopecurus agrestis

Anthemis arvensis " cotula

Arrhenatherum avenaceum var. tuberosum

Carduus arvensis

Cerastium vulgatum

Chenopodium album

Convolvulus arvensis

Equisetum arvense
Galium aparine

Lolium perenne

Poa trivialis

Senecio vulgaris

Sonchus arvensis

Stellaria media

Triticum repens

Veronica agrestis

1 The species was unfortunately not identified, but was probably either G. molle or G. dissectum. 
Anagallis arvensis-(only in very small quantities on chalk).

Euphorbia Helioscopia

$\left.\begin{array}{l}\text { Rumex crispus } \\ \text { Taraxacum dens-leonis }\end{array}\right\}$ especially on chalk.

Geranium columbinum) (Probably some species are specially associated

$\left.\begin{array}{l}" \quad \text { dissectum } \\ \prime \quad \text { molle }\end{array}\right\} \begin{aligned} & \text { with chalk or clay, but there were not suffi- } \\ & \text { cient records to justify such association.) }\end{aligned}$

Any plants not mentioned in the foregoing lists will be found in the following table. Most of these were seen very seldom or only once during the investigation.

\begin{tabular}{|c|c|c|}
\hline Ranunculaceae & $\begin{array}{c}\text { Ranunculus bulbosus } \\
\text { hirsutus }\end{array}$ & $\begin{array}{l}\text { sandy loam } \\
\text { clay }\end{array}$ \\
\hline Cruciferae & Brassica oleracea & chalk \\
\hline , & Cochlearia Armoracia & sandy loam \\
\hline , & Senebiera Coronopus & clay \\
\hline Caryophyllaceae & Lychnis diurna & \\
\hline Papilionaceae & Trifolium repens & chalk \\
\hline$"$ & Vicia hirsuta & sand \\
\hline Rosaceae & Alchemilla arvensis & clay \\
\hline ” & Potentilla reptans & various \\
\hline Umbelliferae & Caucalis nodosa & clay \\
\hline Valerianeae & Valerianella olitoria & chalk \\
\hline Compositae & Bellis perennis & chalk and clay \\
\hline " & Carduus lanceolatus & clay \\
\hline , & $"$ nutans & red land \\
\hline ” & Centaurea Scabiosa & \\
\hline ” & Chrysanthemum Leucanthemum & various \\
\hline , & Lapsana communis & chalk and clay \\
\hline ” & Matricaria inodora & sand \\
\hline Boragineae & Borago officinalis & chalk \\
\hline " & Symphytum officinale & sandy loam \\
\hline Solanaceae & Solanum nigrum & sand \\
\hline Orobanchaceae & Orobanche minor & chalk \\
\hline Scrophularineae & Linaria minor & chalk and clay \\
\hline , & Veronica arvensis & chalk \\
\hline Labiatae & Glechoma hederacea & chalky soil \\
\hline , & Lamium amplexicaule & chalk \\
\hline$"$ & $" \quad$ purpureum & sandy loam \\
\hline ” & Prunella vulgaris & clay \\
\hline$"$ & Stachys arvensis & " \\
\hline Polygonaceae & Rumex obtusifolius & \\
\hline
\end{tabular}


Urticaceae

Liliaceae

Gramineae

,9
Urtica dioica

Ornithogalum pyrenaicum

Avena fatua

Phleum pratense clay and sandy loam clay

black gravel

clay

Comparison of the Weed Flora of the Wiltshire and Somerset DISTRICTS WITH THAT OF EAST BEDFORDSHIRE.

A. Weeds of clay soils.

The general aspects of the weed floras are fairly comparable, both as regards the distribution and variety of the species. Certain differences are however evident, of which the following are the most striking:

Bedfordshire.

Bartsia Odontites

Matricaria inodora

Plantago media

Capsella Bursa-pastoris

Tussilago Farfara

Euphorbia exigua Never seen on chalk various soils tion
West Country

Districts.

Typical and practically Chiefly on chalk; scarce confined to clay. on clay

Very plentiful Totally absent

Scarce ; distributed on Fairly frequent ; practically confined to clay

Scarce on clay Chiefly on clay

Universal in distribu- Chiefly on clay

Scarce; only one re- Frequent; chiefly on cord on clay

\section{B. Weeds of chalk soils.}

The West Country chalk soils exhibit many species of plants, of which a large proportion are definitely characteristic of the chalk. The Bedfordshire soils, on the contrary, have relatively few distinct chalk weeds, of which still less can be called definitely characteristic.

\section{Bedfordshire.}

Lychnis Githago

Silene Cucubalus

Campanula hybrida

Linaria spuria " vulgaris Myosotis arvensis
No record

Symptomatic of chalk

One record ; sand and clay

" " heavy clay

" " chalk and clay

Universal in distribution
West Country

Districts.

Confined to chalk

Also occurred on clay

Symptomatic 


\section{Bedfordshire.}

Poa pratensis

Daucus Carota

Reseda lutea

Chenopodium album

Heracleum Sphondylium

Lithospermum arvense

Papaver Rhoeas

\section{Plantago lanceolata}

" major

Scandix Pecten

Euphorbia exigua

" Helioscopia

Potentilla anserina
One record; gravelly Symptomatic

loam

" , on chalk "

" " " "

No record from chalk Frequent on chalk

Not recorded

Very characteristic of

"seldom recorded from chalk

Universallydistributed

Scarce

Universally distributed

Designated as ' Calcifuge'

No record on chalk
" " $\quad$ chalk

Characteristic of chalk Frequent on chalk

Characteristic of chalk

Frequent on chalk

" " "

Occasionally seen on chalk
West Country
Districts.

\section{C. 'Calcifuges:'}

Of the various so-called 'Calcifuges' of the Bedfordshire districts Poa anmua is the only species which retains that character in the West Country. All the others are more or less associated with chalk.

Bedfordshire Calcifuges.

Alopecurus agrestis

Anagallis arvensis

Euphorbia exigua

" Helioscopia

" peplus

Veronica arvensis

$"$ hederaefolia
Occurrence in West Country.

Recorded several times on chalk; dominant in one field.

Frequently recorded from chalk, but usually very scanty.

Frequent on chalk. ${ }^{1}$

" " "

" $"$,

Only three records, but all from chalk.

Several records from chalk, with one of dominance.

1 In Bedfordshire all species of Euphorbia are apparently absent from chalk, while certain of the species are frequent in that habitat in the West Country. It has been criticized that "it is therefore a mistake to call them "calcifuge", as it can only mean that there is some other factor, commonly present with chalk in Bedfordshire, which determines absence'. Strictly, this criticism is quite just, but for the purpose of this investigation the word 'calcifuge' is used in a restricted local sense, in default of a better term, to indicate the absence of any species from chalk soils in a particular locality. Future work will probably sort out the true calcifuges from the local calcifuges. 
An examination of the above analyses and of the available data shows :-

I. Many of the differences between the two floras are simply differences in quantity, which change the balance of the distribution of the weeds on the different types of soil.

2. Several plants which occur on various soils in Bedfordshire are definitely associated with chalk soils alone in the West Country.

3. Other plants which are calcifuges in Bedfordshire are more or less frequently observed on chalk in the West.

4. A few weeds are recorded from each district which are totally absent from the other. The number of such species, though, is far less than might have been expected, considering the distance between the two localities, involving some difference in climfate and in soil.

\section{Points of Interest.}

I. While the association of particular weeds with certain soils is so well marked, the correlation between the weeds and the crops with which they occur is much less definite. The great majority of species occur indiscriminately with any kind of crop, whether cereals, roots, or 'seeds', the nature of the soil being the determining factor of their occurrence. Still, a few plants do show some correlation with the crop, and to a large extent the West Country results tally with those of Bedfordshire in this respect. The 'seed' crops were chiefly clover, vetches, and a mixture of Italian ryegrass and clover. A very few species were almost entirely confined to such crops, but a larger variety of plants were noticeable on account of their rarity or absence among seeds. Also a very few plants were exclusively associated with cereals.

\section{Weeds only associated with cereal crops.}

Campanula hybrida

Lamium amplexicaule

Lapsana communis
Poa trivialis

Potentilla reptans

Ranunculus arvensis

Weeds only associated with seed crops.

Arenaria serpyllifolia

Cerastium vulgatum

Geranium columbinum
Geranium dissectum molle

Sherardia arvensis

$$
\text { Weeds absent or very rave in seed crops. }
$$

Arrhenatherum avenaceum var. tuberosum

Heracleum Sphondylium

Lolium perenne

Mentha arvensis
Plantago media

Poa annua (though once dominant among seeds)

Triticum repens

Veronica hederaefolia 
A number of species which were absent from seed crops in Bedfordshire frequently occurred in association with them in the West Country. This may partly be due to the fact that a large proportion of the clover and rye-grass crops had only recently been seeded, and had made little growth owing to the long drought. In consequence the weeds had not suffered so much from the overshadowing effect of the leafy crop. Under the circumstances the occurrence of such weeds in conjunction with seed crops lends support to the hypothesis that their absence, when it occurs, is due to the starvation of light or air by the crop rather than to any inherent antagonism between the two plants, weed and crop. It is noticeable that the number of absentee species in the West Country records is only nine, as against twenty-one in the Bedfordshire lists.

2. Couch or Twitch was frequently noted as a troublesome weed, but as a general rule only two species were designated as such, instead of the halfdozen met with in other places.

(a) Triticum repens-the true Couch.

(b) Arrhenatherum avenaceum var. tuberosum-the 'Onion Couch', or 'Knotty Couch'. This is one of the worst of weeds when it occurs in any quantity, as it easily spreads and is most difficult to eradicate on account of its swollen tuberous stems, each joint of which will develop into an independent plant if detached.

3. In one instance the most pestilent weed was Avena fatua or Wild Oat, which existed side by side with the 'Onion Couch'. This weed is particularly troublesome, as

(a) it spoils the crop;

(b) it spoils the sample of corn ;

(c) it gets into the thrashing-machine parts and clings together by its hairs until it blocks every outlet.

4. Equisetum and Coltsfoot did not occur in company so frequently as they did in Bedfordshire. The Coltsfoot was more often associated with clay soils, but as before the distribution of both weeds was general. It has been suggested that the presence of Coltsfoot is an indication of the nearness of underground water, and that the plants can only thrive if they can send down their long roots to tap it. This idea, however, needs confirmation.

5. Two plants are totally different in their habitat in the two districts :

(a) Bartsia Odontites, which is a clay weed and calcifuge in Bedfordshire, is practically absent from clay and is very frequent on chalk in the West.

(b) Chenopodium album, which is never recorded from chalk in Bedfordshire, is noted more frequently from that habitat than from any other in the West. 
6. Rhinanthus Crista-galli, Yellow Rattle, was very prevalent in some places in the West. Generally this is a weed of pasture land, but in one case observed the barley crop was full of it and was utterly ruined by it. Some seasons are far more favourable to the growth of this weed than others, though in both I9IO and I9I I large quantities have occurred in this particular district.

7. The total absence of Mayweed, Matricaria inodora, was very noticeable. A small amount of Anthemis sp. occurred in places, but the plants rarely attained any size, and so a very conspicuous feature in the weed flora of Bedfordshire was missing in that of the West Country, on similar soils.

8. Where two or more species of the same genus occur as weeds, it frequently happens that the species differ among themselves in their distribution, being associated with different types of soil ; e. g.-

Euphorbia exigua

" Helioscopia

Plantago lanceolata

" major

" media

Poa annua

" pratensis

” trivialis

Ranunculus acris

$" \quad$ arvensis
$" \quad$ repens

Rumex Acetosella

" crispus chiefly on clay

" "chalk

chalk only

chalk and clay

clay only

chiefly on clay

chalk

distributed

clay and sand

clay

chiefly on chalk

acid sandy soil

chiefly on chalk

\section{SUMMARY.}

I. In each district investigated a definite association exists between the species of weed plants and the soil on which they grow. This association may be either-

(a) Local. When a weed is symptomatic of a certain soil in one district but is not so exclusively associated with it in another.

(b) General. When a certain species is symptomatic or characteristic of the same type of soil in different districts.

2. In most cases there is no association between the weed and the crop, though a few species do show a relationship. The weeds usually found in 'seed' crops appear to be constant, and certain other plants exhibit 
the same association with particular types of crop in Bedfordshire and in the West Country.

3. The relative prevalence of the weeds varies somewhat in the different districts, certain species which are more or less common in one place being practically absent or very scarce in another, on similar soils.

In conclusion I wish to tender my thanks to $\mathrm{Mr}$. E. S. Beaven, who has given me every possible assistance, both by putting me into touch with various farmers, and by the personal interest that he has taken in the work, together with much friendly advice and criticism. Also I must express my indebtedness to all those whose land came under investigation, for their unfailing kindness and readiness to facilitate the work. 


\section{$2 \mathrm{BHL}$ Biodiversity Heritage Library}

Brenchley, Winifred E. 1912. "The weeds of arable land in relation to the soils on which they grow. II." Annals of botany 26, 95-109.

https://doi.org/10.1093/oxfordjournals.aob.a089391.

View This Item Online: https://www.biodiversitylibrary.org/item/236773

DOI: https://doi.org/10.1093/oxfordjournals.aob.a089391

Permalink: https://www.biodiversitylibrary.org/partpdf/319894

\section{Holding Institution}

Smithsonian Libraries

\section{Sponsored by}

Biodiversity Heritage Library

\section{Copyright \& Reuse}

Copyright Status: Not in copyright. The BHL knows of no copyright restrictions on this item.

This document was created from content at the Biodiversity Heritage Library, the world's largest open access digital library for biodiversity literature and archives. Visit BHL at https://www.biodiversitylibrary.org. 